BogusŁaW BAKUŁA

Uniwersytet im. Adama Mickiewicza w Poznaniu

1956, 1968, 1981: The Faces of Central-European Memory: A Postcolonial Perspective ${ }^{1}$

\title{
1. History and Memory
}

If we imagine the culture of Central Europe as a system of separate but interacting collective memories of the past, ${ }^{2}$ it will probably be a truism to state that this situation is not only a matter of factography, but largely of axiology. Researchers dealing with this issue understand, especially with regard to the intercultural and inter-ethnic aspect, that collective memory stems from the fact that next to shared places (we will define this notion as communities of positive memory) there are equally important, or perhaps even more important, separate places, which we can refer to as communities of negative memory. This is especially well known to researchers (imagologists) who deal with images of otherness in a given culture, and also to writers, politicians and specialists in historical politics. The collective memory of the past is also shaped by a phenomenon that we can call non-memory. It is a rarely opened gravesite, into which communities cast everything that they do not want to know, remember, individually

1 This text was delivered during an international conference organized in the Hungarian Parliament in April of 2018: A Nemzeti Emlékezet Bizottsága és a Kelet-és Közép-Európa Kutatásáért és Képzésérrt Alapitvány konferenciát szervez VISEGRÁD - KÖzÖS EMLÉKEZET? 1956 - 1968 - 1981 címmel.

2 This is what Barbara Szacka calls memory. Her work in the Polish field has been considered fundamental since the 1970s. See Barbara Szacka, Czas przeszly: pamięć - mit. 
or collectively, and watch over this state of affairs for as long as they need to. Collective memory of the past, writes Polish researcher Barbara Szacka,

is an image of a communal past constructed by individuals from the information they remembered, according to the rules discovered by psychologists, which stem from various sources and which reach them through various channels. They are understood, selected and transformed in accordance with their own cultural standards and beliefs (44).

Collective memory introduces the past to the world of subjective values and rules that are shared by a given community, thus defining the community's self-image as well as its status. Although it may result from recorded history, memory can also exist independently of it, fueled, for example, by spoken history, family stories, social legends, tales of a mythical nature, etc. If we approach history as a separate, institutionally sanctioned narrative in writing (dictated by pragmatic, objectified rules of a given period), then memory becomes its competitor, as it presents a slightly different, sometimes even a completely different, version of the past. History and memory compete with each other, although they emerge from one another and need one another. The carrier of history is writing (logos), while the carrier of collective memory is consciousness (psyche). Collective memory primarily preserves emotionally and axiologically selected components of the past. There are societies devoid of institutional history, but with enormously complex mechanisms of collective memory that are based on moral, mythical, clan, religious and other principles.

It should come as no surprise that there is a discrepancy between memory and recorded history, which has been extracted from archives and written according to established principles. These are two different, though related, levels of collective remembering; it is enough to recall what history and what communities say about, e.g. the crime in Jedwabne or the so-called "cursed soldiers" in Poland, about the Slovak participation in the attack on Poland on September 1, 1939, about the attitude of the Ukrainian society to the Volhynia crime and about many other issues that inflame the historical imagination in Central Europe. There may be cases where history and memory overlap. Usually, this occurs when the collective psyche is not able to construct knowledge on account of it being separated from internal and external sources of information and of its limited scope of control. Then, it often relies on a recorded and imposed image of the past. This image is a rather theoretical construction, which is why it is usually presented in literature as a negative utopia, where the past is reduced to one doctrinal interpretation, and the community suffers from real or just imposed 
amnesia. This is a feature of totalitarian (political and religious) systems, where control extends not only to recorded sources, but also to our awareness by way of doctrinal education. Differences between collective memory and historical memory, researched, among others, by Jacques Le Goff, Maurice Halbwachs, Paul Ricoeur, Pierre Norra, Jan Assman and Aleida Assman, and in Poland by Barbara Szacka, Andrzej Szpociński and Marian Golka, are still not easy to precisely define. Most historians and sociologists consider collective memory as a type of error-laden knowledge, subjective, incomplete, with undetermined, fluid boundaries. ${ }^{3}$ Regardless, memory in a given community is one of the basic mechanisms of collective functioning, without which there would be no way to discuss nation, class or regional identity. Halbwachs would add that every social group (especially national), as well as an individual, has different types of memory, which is associated with belonging to specific communities. This also applies to generations and families. ${ }^{4}$

In this statement, I emphasize the role of collective memory, distinct from history, as a sphere that remains only marginally utilized by institutions of power. Memory enters into relationships with written history, because history is one of its sources (and conversely), but at the same time it contains what history does not want or cannot collect; for example, the emotional and spontaneous side of collective experience, the private and family events that escape the narrative of power (history written in textbooks is also an instrument of power). If we assume that history is conventionalized writing, through which a specific power model is implemented, and memory is a dynamic psychological process (discontinuous, nodal, non-holistic), we can accept another assumption that results from the axiological essence of memory. It is related to the aforementioned shared memory (the community of positive memory) and separate memory (the community of negative memory). It is not particularly revealing to say that memory can divide and that which is shared always causes a reaction in the sphere of experienced separateness. This is an important psychological mechanism that functions in social space, but is also sometimes used politically.

3 In summarizing this difficult issue, Krzysztof Malicki (2012) states the following: "Examining the social memory of the past (collective memory), we are examining to a certain extent historical consciousness understood as a state of knowledge about the past its appropriate valorization. Szacka also emphasizes that historical knowledge, which contributes to collective memory (social), is subject to selection and distortions in line with the demands of collective memory. In such a memory there is no place for ambivalent stances, and the figures and events are either good or bad." Quoted in K. Malicki. Pamięć przeszłości pokolenia transformacji. Warszawa: Scholar, 2012.

4 See Maurice Holbwachs's Społeczne ramy pamięci. 
Shared memory will contain connecting elements, mutual relations and the same or similar events, which are evaluated in a similar way. It is different from separate memory on account of its axiological aspect. In the first case, there is a focus on searching for possible areas of dialogue. Shared memory includes the voices of Others. In the case of separate memory, it is important to emphasize one's otherness, disbelief towards others, which are not always completely other, reproducing narratives about one's own singular experience, about its untranslatability, uniqueness and other commonly known assessments. It should be once again emphasized that shared and separate memory are, therefore, axiological categories. At this point, we can talk about their retroactive effect as a process of continuous valorization of the past in the consciousness of the nation or a social class. This valorization takes place through ongoing collective debates, but also as a result of the pressure exerted by historical events, as a result of collective religious experiences, and, in an extreme case, it can be imposed by a dominant political force (what is recorded will become history). Certainly, this valorization also results from the structure of a given society, its internal dynamics and openness, or, conversely, from the dominance of a closed, static attitude, characterized by a kind of collective catatonia caused by historical traumas.

What remains outside shared memory will here be referred to as separate memory. These include cherished images of the past that, for various reasons, are not negotiated. Shared memory (spontaneous as well as planned) usually functions in the sphere of inclusive activities. By contrast, separate memory functions in the sphere of exclusive events. Memory works inclusively when it absorbs and merges various memories and intentions into a construct acceptable to many entities. The purpose of this activity is to reach an agreement, even in basic matters related to a past that connects the interested parties. Exclusivity of memory works only when it excludes, separates, when it emphasizes separateness, and also when it marginalizes, segregates, stamps out the attitudes, facts or opinions that are regarded undesirable from the collective point of view. Generally speaking, memory works in both aspects (shared and separate) and on both levels simultaneously (inclusive and exclusive), and takes into account purposefulness and spontaneity in a multi-subject system. Non-memory, in turn, is an equally important mechanism with which both of the previously mentioned types of memory reject what, at a certain historical stage, lies beyond the reach of rational criticism, and thus becomes taboo, a closed world, unverifiable, traumatic, because a given community, for reasons that it understands or not, attempts to push particular information out of the discourse or hide it effectively enough that it does not participate in the creation of both shared 
and separate memory. It is impossible, however, to say that this information is not there, since we do not know what resides in non-memory.

The above outline demonstrates that collective memory is a very complex mechanism of repeating, saving, transforming and concealing information constituting the collective identity. Specific problems in the sphere of shared and separate memory as well as non-memory in Central Europe result from the thousand-year-old relationships with many neighboring nations, which have abounded in various systems of domination and subordination, but also in long-term alliances and cooperation. Shared memory is not a panacea for the trauma of nations and individuals, although it can give an illusory sense of alleviating them. Separate memory does not entail declarations of war, nor does it mitigate the solitary experience of trauma, when Others do not understand or do not want to understand what we have experienced and how these experiences are rooted in our collective and individual consciousness, and probably also the subconscious. The final result of forming shared-separate memory will not be the relief of attaining objectified (being the result of conscious work) truth (because it will not be found), but a subjectively created identity, both collective and individual. This identity will be based on inclusion and acceptance or on exclusion and negation. Usually, both forms function in parallel, though unevenly, so one should assume that they may operate simultaneously, though disproportionately. Separate memory usually dominates, but its role can be seen only in the context of what we call shared memory. In other words, memory is not only a specific type of knowledge, but also a way of experiencing it. This gives rise to people assuming specific attitudes and often making very extreme assessments; it gives rise to forms of sanctifying the past, to personal, family and social rituals, to means of communication through acceptance or negation.

In addition to the mechanisms of maintaining or duplicating, which are called memory, we understandably encounter forms of intentional non-remembering. We do not remember what is shared. And we do not remember what is separate. Non-memory can refer to history as well as to the spontaneous, collective memory of the past. It is important to once again emphasize that separate memory is primary for each national community, because thanks to it nations take shape and function alongside others. In turn, shared memory, which goes beyond the limits imposed by ethnicity, is a margin that is useful as long as it does not constitute an internal problem. Shared memory is an instrumental bridge used to communicate with the Other. It can be created and it is more flexible than separate memory. In its aura, it is also easier to reach the sphere of non-memory. 
Shared memory can be expanded and made into a strong unifying argument in terms that transcend ethnicity. There is after all such a concept as the international community of memory. The memory of the international community has the same features as "internal" collective memory, but is more the result of negotiations. Its existence (in a positive or negative variant) is contingent on an adopted consensus; however, the memory of the international community is not merely a planned construct; it is also, to a certain extent, spontaneous. The short history of the European Union is built on the negotiated area of shared memory and it is a history that is also not indifferent to matters that could not be negotiated, which proves how far it can be disrupted by activated factors of separate memory.

During World War II, Central and Eastern European countries were in different political constellations; they also had divergent territorial, economic and national (national) interests. Their common framework was more or less clearly dependent on one or two hegemons: the Third Reich and the Soviet Union. At the same time, the Poles were fighting against Nazism and communism; Ukrainians from Galicia against communism and the Poles, but under the command of the Third Reich; The Slovaks and Hungarians were fighting against communism while under the protectorate of the Third Reich, as were the Romanians, but at the same time they were essentially conflicted with each other, burdened as they were by the recent memory of mutual exclusions, aggression and annexation. The Slovaks were divided into a pro- (anti-Hitler and pro-Soviet Slovak National Uprising) and an anti-communist faction, while being decidedly opposed to Hungary's policy towards parts of Slovak lands. The Czechs ideologically stood against Nazism and Germany, counting on the helping hand from the Soviets and Western Allies, while simultaneously partially cooperating with the Third Reich; this put them in a state of mental war with Poland, which after the fall of Czechoslovakia occupied Zaolzie and was already involved in a growing conflict with the Third Reich. Such various engagements intertwined, creating a unique situation in the region. The shared (in terms of similarities and differences) history of Central European countries during World War II does not determine shared memory (community of positive memory), but rather draws out separate memory, if not the memory of conflicts (community of negative memory). Thus, everything that has been discarded from memory, either successfully or not by means of distorting the past, still remains a topic of inquiry and is shocking when brought to light.

Some will simply say that Central Europe is extremely divided in terms of history, but above all memory, and there is an abundance of evidence in support of this claim. Their search might take them to the nineteenth century, when 
radically different assessments regarding the revolution of 1848-1849 can be found, and to the twentieth century, when there were differences regarding the relationship of Central European nations and states to the Versailles order (including the Treaty of Trianon) and the post-Yalta order, and then the issue of Central European countries' participation in World War I and II, the degree of their involvement in the Holocaust, their participation in establishing communism, and then its demolition, etc. Historical problems and proportions are to some extent leveled after 1948, when all of Central Europe, together with a part of Germany, was united into a communist dependency system, and various contentious issues were suspended in the name of the communist friendship of nations. The artificially created shared history of the "socialist nations" had a clearly ideological character and was devoid of any conflicts (which did not mean that they were suddenly overcome). Attempts to bring the communist vision of history to fruition and build a shared memory based on this vision ultimately failed. The collapse of this "community" after 1989 almost immediately resulted in the appearance of history and separate memory. In the $1990 \mathrm{~s}$ and at the beginning of the current century, instead of socialism, we there appeared more or less artificial projects committed to creating a politically and economically unified Central Europe (the Visegrád Group). Today, we can see that they have also not been successful.

In Central Europe, therefore, we have a shared history, recorded in one ideological convention or another, which is not always accepted in the less institutionalized spaces of collective life. This is why for many social groups, a separate, spontaneous memory, one that is not associated with the institutions of power, became an alternative with definite moral character. What is more, it is separate memory that, in the opinion of the Central European nations, testifies more to identity than a shared history and the so-called shared memory (sometimes considered a manipulated memorial community). It is enough to look closely at Slovak-Hungarian or Polish-Ukrainian relations. Slovak memory and the identity it helped to create are still shaped in spontaneous accounts as anti-Hungarian (against the Hungarian historical narrative and memory), and Ukrainian identity is presented as anti-Polish (similarly directed against Polish interpretations of mutual historical relationships and cultivating a radically separate memory and is clear proof for the existence of non-memory). This situation should not completely destroy the status of shared memory that aims to build close and positive relationships, but we will admit that in the present era, separate memory plays a more constitutive role. Of course, theoretically the best situation is to strike a balance between both types of memory and thus achieve a harmonized, non-antagonistic attitude to history. 
When approaching the shared memory of events in Central Europe from 1956, 1968, and 1981, we must be aware of all the events and mechanisms listed here that occur synchronously, although disproportionately (in every society differently) in history. Therefore, we must ask whether we mean shared history (textbooks, monographs, and political integration campaigns, etc.) or shared memory (social memory and also art in a broad sense) or about other, less significant "memory" phenomena (e.g. mythicization in artistic fields) that can be distinguished. It is also worth asking why we do it? Are we really interested in writing a shared story or communicating in a shared memory?

Someone may first ask if we even need a shared memory in a broader, international sense. Is it not better to remember separately (for example nationally) and act together when possible through specialized institutions? Others will say that we can remember together if possible, but must act separately, sovereignly, and form pragmatic alliances. And they will also find support. In Central Europe, all "memory" phenomena are still intentionally complicated, morally undefined, requiring a number of concessions and the acceptance of hitherto unaccepted positions. Therefore, I will state the bold thesis that there is no such thing as shared memory (community of positive memory) in Central Europe and there is little indication that this state of affairs will change. Of course, there is a whole set of key words, slogans, anecdotes or even wider narratives that display the category of shared Central European memory. Usually, however, this happens in the specialized, narrow corridors of culture and includes a small portion of collective memory. The word "shared" is key here, as it relates to intentions and the possibility of implementing them. Although we know that theoretically the possibilities in this field are considerable, the practical implementation of inclusiveness has proven that these possibilities are in fact quite modest. However, because total inactivity in the area of shared memory threatens to render each long-term activity dysfunctional, separate memory and non-memory do not always have to entail exclusivity. For pragmatic aims (somehow you have to function with one another) and nostalgic aims (the past is always morally better than the present), the image of a Central European memorial community has for years been presented as a beautiful, though lost, order. Thousands of books have already been written on this subject. However, not one was written which synthetically presents history in a way that would not trigger any protests from other nations and states. This demonstrates the difficulties in practicing so-called shared memory in Central Europe or, more broadly, in Central and Eastern Europe. 


\section{What are we talking about?}

The years 1956, 1968, and 1981, being as they are important milestones in the experience of four Central European nations, provide us with a good excuse to reflect in a conciliatory manner on inclusivity and memory. What comes to the fore is what the nations of our region celebrate the most, when commemorating the tragic events of their own past. The most important factor in constituting a community is the cult of victimhood; centuries of cultivating traumas resulting from the loss of independence. Victimhood culture reaches its heights in this region, as does literature that is infused with victim mentality, although the Czechs managed to some extent to break free of this complex in the twentieth century and relieved this tension in a literature that demythologized the imposed k. und k. monarchy. Sometimes, however, doing so is not possible for objective reasons, and then the conviction remains that whoever has it worse is nobler, better and even smarter. Before our eyes unfolds a spectacle of publically (internationally) displaying our suffering. In most cases, this suffering is genuine and terrible. The years marked by disaster 1939, 1956, 1968, and 1981 are ineludible to Central Europe, although, certainly in terms of development, three other years are more important, more widely extended, and treated as processes: 1918-1920, 1944-1945, and 1989-1991. They mark state-forming events, while the former denoting the destruction of the emerging order. Even 1945, which marks the beginning of a new occupation, seems better than 1939, because the end of World War II will be considered a better time to live than its beginning.

The years 1956, 1968, and 1981 denote specific moments in the internal history of Central Europe. They represent an attempt to change the existing system, though, it would seem, without radically undermining its foundations (reforms); armed invasion of reforming countries; large casualties, followed by even greater ones on account of prolonged repressions. The collective memory includes the following: the armed, heroic resistance of the Hungarians, the crushed gentleness of the Prague Spring, the pervasiveness of change being sought in Poland. On the other hand, to this day, part of the Hungarian and Czech society remembers the Polish strikes of 1980 and 1981 as it was presented by propaganda as idleness for which others would have to pay; some Poles saw in the Czechoslovakian reforms of 1968 as a continuation of imposed socialism (thus as an uprising which only sought to improve the content of the plate), and they would continue to remind the Hungarians of their cooperation with the Third Reich, which was meant to "explain" the ruthless behavior of the Soviet occupiers in 1956. At the same time, Poles supported the Hungarian Revolution of 1956: blood was donated to the injured Hungarians and planes were sent 
to Budapest with supplies. The telling silence of the Slovaks with respect to the Hungarian uprising will be compared with the positive interest the Hungarian society expressed in the transformation plans in Czechoslovakia in 1968. However, what the people remembered is in no way connected with the findings of historians and does not always appear as a memorial community that is understood in a positive way.

Anniversaries can be celebrated, visits paid, monuments erected, but these are signs of internal memory, not shared memory in the strict sense. What exists in the internal national discourse of each of the Central European national communities is, therefore, very diverse. National holidays in some countries will incite protests of others, as is the case in Slovak-Hungarian or Polish-Ukrainian relations. Therefore, it can be said that history extracted from prejudices has more positive arguments in favor of building an image of a positive community, while memory does not offer solid reasons to build an international community. It would seem that there are no better reasons to create it than these dates. Surprised at what I have arrived, I would like to react to this thesis by recalling the perspective in which the various experiences of enslaved peoples are investigated-the postcolonial perspective.

\section{Postcolonial Perspective}

Perhaps postcolonial theory will help us understand some issues related to memory. This theory provides tools for studying the processes that occur in societies of the so-called former subalterns and compradors, (terms used by leading Western researchers of this trend, such as Homi Bhabha, Gayatri Spivak, Dipesh Chakrabarty, Ewa Thompson), or the subordinated and collaborators, in a world where the memory of different forms of enslavement still persists and where the acquired reflexes of opposition or resentment, which are the heritage of trauma, act spontaneously. The difference between a subaltern and a comprador is that the former resembles more a slave (despite himself), while the latter is usually a member of the local elite in charge of the machinery of enslavement (a minion, a poputczik, a volunteer). The arrangement between them, even after the formal collapse of colonization, i.e. the system of mutual control and even further enslavement, may still resemble a colonial structure, though without a foreign factor. A comprador takes over some of the functions of a hegemon and strengthens its position, because he knows how to govern. It will take some time for people outside the circle of former compradors to come to power and shape history. The position of the subaltern and comprador towards the hegemon (colonizer), along with the political, social, cultural relations between system 
members, constitutes a starting point for any consideration of colonial and then postcolonial frameworks. Subordinated and desubjectified after the departure of the colonizer, they experience a phase of violent opposition to the colonial past, and then move on to phases of diverse, mutual political, economic and cultural relations. Their elites are beginning to intermingle, creating a shared environment of the new government. Shared memory, therefore, would be, in these conditions, a memory that inherits the remains of various historical and political addictions, which is why it is built on the basis of a momentary consensus (some will use the term "rotten compromise").

Western postcolonial thought emphasizes the issue of domination and violence, taking aim at actions that legitimize these practices. Much has already been written about dependence in culture, economy and politics. Another aspect of this dependence is related to the active ideology of victimhood of Central European subaltern (martyrdom), combined with the nation's or class's conviction of their unique mission. This is accompanied by continuous existential traumas and various forms of accentuating martyrdom that result from past suffering; a strong nationalism emerges. Researchers say that these beliefs in the postcolonial world are the foundations of collective memory and, therefore, of identity. This also affects the possibilities of the task of shared memory as well as its assessment. It is not certain that the postcolonial hybrid personality, which is a product of one's own culture and that of the colonizer, will be the depositary and the representative of shared memory. Most often it is the other way around.

Of course, we are discussing here mass processes, and not individual attitudes that are manifested in literature exposing postcolonial complexes, e.g. Salman Rushdie's novels. In Central Europe, examples of a postcolonial discussion in which the issues raised above are important can be found in the literary works of Witold Gombrowicz, Sándor Márai, Milan Kundera, and Ladislav Mňačko. It is not surprising that these writers are immigrants living after the Second World War in a free world, away from local dependencies.

In the context of postcolonial studies, four aspects of collective memory appear to be important, as they have an impact on the creation of shared/ separate memory. It is ressentiment, recollection resulting from the regret of the defeated and unremembering, which is the result of guilt, a manifestation of a desire to partially forget. Part of the memory functions here as a whole, displacing uncomfortable elements due to regret or shame. On the other hand, planned activities, such as historical politics, whose essence is adaptation and the pragmatic selection of the past, appears as a component of memory; aesthetization, i.e. the desire to change the pragmatic code of memory into a symbolic 
code, e.g. literary, theatrical, etc. Aesthetization means shifting the discussion from the issue of responsibility to that of beauty of expression and metaphors, broadly encompassing the human condition. Distinguishing "shared memory," symbolized in Central Europe by the selected years 1956, 1968 and 1981, takes shape in the four aspects as an inclusive and exclusive process, and, at the same time, one that is politically pragmatic and spontaneous.

\section{Postcolonial Morphology of Shared Places}

Let us begin with ressentiment, which has acquired a significant body of research in the fields of philosophy, ethics and psychology. Suffice it to mention such works as Friedrich Nietzsche's From the Genealogy of Morals and Max Scheler's Ressentiment and Morality. Ressentiment describes the creation of false values and moral assessments in compensation for one's own weaknesses and limitations. It is a kind of symbolic revenge on the hegemon. The essence of ressentiment can be described as reminiscing and commemorating on lost causes, which are then refashioned as victories, exalting defeat and sacrifice, and celebrating the moral fall of the hegemon. Nietzsche wrote that ressentiment is a feature of slave morality. Developing the concept of ressentiment based on ethics and axiology, Scheler claimed that, "The basic starting point in ressentiment is the reflex of vengeance" based on powerlessness and manifested in symbolic gestures. Vengeance is an axiological illusion, an "illusory falsification of values," which means that "man lives in a false world of appearances." Ressentiment is "spiritual poison." "Ressentiment is born when we are humiliated by our own impotence," (Bartoś) adds the Polish philosopher Tadeusz Bartoś. Ressentiment played a large role in the assessment of the events that took place in 1956, 1968, and 1981 (similarly to the assessment of the Warsaw Uprising of 1944 or the Slovak National Uprising). In addition, ressentiment meant that it was possible to draw analogies between rebellions, build ideological and moral bridges between the dissenters, and assess the crimes committed by the hegemon. This was made possible by the silence of the neighboring countries, which for the most part passively observed the Soviet invasion of Hungary. These countries did not respond to the Soviet invasion in 1968 (and even participated in it) and they also supported martial law in Poland in 1981. Everyone resented someone for something and it was difficult for anyone to speak about overcoming the resultant prejudices and barriers.

5 See Max Scheler's Resentyment i moralność. All the quotes are from the first chapter titled "Przyczynek do fenomenologii i socjologii resentymentu" (31-32). 
Ressentiment incites strong emotions, while unremembering is an attempt to extinguish this fire. Unremembering means recalling the past, but without its historical structure, details and meaning. In the world of ressentiment, the past hurts, but in unremembering it makes sense to blunt the pain, deny it, replace it with a milder attitude, expressed by a playful relation with the colonizer, by using Aesopian language, rejecting the attitude of open rebellion, because "you need to live somehow" and "heal wounds." We read the past here from the point of view of the current state of affairs, which is adapted to the existing circumstances. The past is, therefore, recognized as an important general experience, one that imposes itself as an essential exponent.

There is ample evidence that the mechanisms of memory described here exist and that they are related to specific events in history. Ressentiment will suggest that the national uprisings of 1956 (the Polish uprising in Poznan and the Hungarian in Budapest) were suppressed by the invaders, but also by collaborators and traitors. In Poznań, it was not the demonic Soviets, but Poles who shot at the protesting children and workers. However, not much is said about them, as such details do not conform to the narrative of national solidarity that appears there. The mechanism of unremembering will probably stave off the fact that the attempt to revise Stalinism in Hungary was initiated by a faction of the communist party. The communist Imre Nagy defended his homeland not only from the Soviets, but from members of the communist party, because he wanted another kind of communism. He was murdered in retaliation. Director Márta Mészáros commemorated Nagy in the film A temetetlen halott (The Unburied Man, 2004), but the issue of rehabilitating a murdered communist sparked opposition in Hungary. Just as we are certain that the cult of victimhood exists and that Nagy was more of a patriot than a communist, we are also almost certain that Hungarian cooperation called "goulash communism," which was caused by repressions, and the Polish "little stabilization," which was the result of the defeated ideals of the "thaw" and the shock following the Poznan repressions, will not fully enter into the canon of collective memory. Ressentiment screams, while unremembering insists on silence.

Although little is still known in Central Europe about the Polish "solidarity" of 1981 and its end, i.e. martial law, there is an ongoing dispute in Poland that is important for the emerging shared memory. The problem concerns the identity of many leadership groups who would like to, in one way or another, take administrative control over memory of that period. Here, it is difficult even to form an internal shared memory. Thus, the mechanisms of unremembering prevail, altering hierarchies and roles. Behind the dramatic disputes, there also lurks the abyss of non-memory, which is convenient for newer power groups 
that historically do not have much in common with the first Solidarity movement and resistance during martial law. There are those who, at the beginning of the transformation, did missed the chance to enter the great political circles and take part in international life. For this reason, the kind of resistance that looks best both in terms of historical politics and aesthetics is one that is reduced to sacrifice-preferably anonymous. The collective memory of Poles faces a difficult task of valorizing the birth and fall of the first Solidarity movement and the emergence of a collective resistance in the 1980s. This period has not yet been noticed and understood in Central Europe. Today, we still bear witness to its deformation by separate memory.

We remember 1968 as the end of the illusions Czechs and Slovaks had about socialism with a human face. This time this was a joint external invasion. The subalterns, willing or not, attacked one of their own in an attempt to silence a country as it tried to change the rules binding it to the hegemon. The invasion resulted in failed reforms and "normalization," during which the majority of Czechoslovak society accepted the so-called "dumpling communism." In exchange for a raised standard of living, they silently turned a blind eye to the repression of dissenters. Is there even the issue of shame for the silence of Central European societies in the face of such overt violations of international law and norms? In Poland, only two writers objected openly: Sławomir Mrożek and Jerzy Andrzejewski. Most Poles at that time supported the authorities' anti-Semitic internal policy and Czechoslovak affairs were relegated to the background. The intermittent embarrassment stemming from those attitudes will have difficult access to shared memory. And in this case, too, there will be an inevitable unremembering of certain events or aspects of the past, allowing this outline of shared memory to create at least a semblance of comfort.

The joint invasion of Czechoslovakia led to, among others things, the division of the country, which on October 28,1968 , became a federation. The division was created by Slovak communists, to whom the Soviet hegemon conferred power, as it distrusted the rebellious Czechs. In 1993, this facilitated an almost instant division into two organisms and the emergence of a sovereign Slovakia. Is it possible, therefore, to consider such collaborators as Gustáv Husák, Vasil Bilak, or even the communist Alexander Dubček, regarded in his time as a hero (of course also Leonid Brezhnev and his Kremlin companions), as unwitting forefathers of today's Slovak independence? There are voices commenting on the paradoxicality of history. Post-communists will keep this in mind when (if!) they come to power one day. Mentioning the paradoxical role of Husák, Bilak and others may be an obvious mistake, but it can also prompt a discussion of what will be remembered of the "normalization" period. This discussion does 
not have to conform perfectly to the concept of a mandatorily decommunized Slovakia and a decommunized shared memory. That is why we will be more willing to unremember this story and base our shared memory on ressentiment which directs our attention towards the brutality of the invasion, the heroic response and the incurred sacrifice.

Poland experienced the year 1968 and what was left in the aftermath; it was torn between student protests, writers defending free speech and an unleashed, vulgar anti-Semitism, which led to the expulsion of several thousand Polish intellectuals of Jewish origin. What aspects of this difficult moment will pass into shared memory? Will it contain the student rebellion and the struggle of several dozen writers for free speech in a world of primitive violence? Perhaps some regret will remain over the unjust expulsion of people, many of whom were authority figures and world-class intellectuals. Yet, the anti-Semitism of most of the society was unremembered, decomposed, erased from a sense of responsibility. The feeling of shame about these events will probably not enter the shared memory of the Visegrad countries. Everyone knows that when you look for a speck in your brother's eye you will end up with a plank in your own. The postcolonial perspective shows different layers of the past and memory, and their integrity as a community can be put to the test.

In Central Europe, the German term "historical politics" has gained currency. One of the definitions of the term states that it is "[a] conscious effort on the part of the political class to shape the scope and nature of collective historical memory" (Wolff-Powęska 3), we should add, with the intention of consolidating views, thereby allowing the authorities to legitimize controversial goals. Practicing historical politics began to have a real and negative impact on entities that were once in difficult relations of dependence, and today are building new relations. Buttressing the shared memory of Central European countries on the events of 1956, 1968, and 1981, which have been emotionally constructed by ressentiment and unremembering, may bring it closer (though not necessarily) to a pragmatic historical politics, which are in service to the current goals of the institution, especially the state. There are many other important dates and many other memories. Every country and nation has the right to emphasize its own history, but we know from experience that actions motivated by historical politics can also have repercussions for shared memory. Such repercussions were caused by the amendment to the Act on the Polish Institute of National Remembrance adopted at the beginning of 2018. The amendment, which was concerned with the criminal consequences of defaming the Polish nation with spurious accusations of Polish crimes against other nations, raised the issue of this "lying" as an excessively broad category. This kind of legislation by Polish 
parliament caused consternation in Western and Eastern Europe, upsetting Polish-Israeli, Polish-Ukrainian, Polish-German relations, and probably also others. Its purpose was to unremember history and its ideas in order to build a better, shared memory. Meanwhile, the opposite happened. Its creators, under the pressure of international opinion, had to remove sections of the legislation that reeked of manipulative historical politics.

Aesthetics opposes the failures and successes of historical politics, which is essentially spontaneous, in much the same way a work of art can be spontaneous. In The Location of Culture (1994) Homi Bhabha warned against aestheticization as an illusory process of alleviating traumas However, it must be admitted that aestheticization is an activity that works relatively best among the memorial techniques shown here. An excellent example in Polish literature is the socalled borderland prose, which is unparalleled by any other literary trend due to the diversity of the displayed historical inter-ethnic relationships, as well as the richness of the presented memorial space, ${ }^{6}$ referring primarily to the history of Poles. However, what is Polish and what is the most valuable element for national memory are (can be) regarded as an antithetical value in other national discourses.7 That is why idealization is elsewhere unmasked, aestheticization, as its received, succumbs to narrowly understood political pragmatization, and dialogue provokes exclusion; and these are mutual reactions, often appearing from several directions at the same time. It is rare for artistic works to actually create a shared space of memory, which is why accomplishing this feat by other documents is all the rarer. There is much in Polish literature about 1956, more often about the revolution in Budapest than in Poznań.

The post-Stalin "thaw" turned out to be a theme almost unnoticed by Czech and Slovak literature, because it did not exist in reality. Delaying the Czechoslovak thaw by a decade changed its character, purpose and meaning. It also enabled this cold history to be captured in terms of a sophisticated irony. This was the only way to overcome the inertia of memory and the void of ressentiments, as well as political manipulations. Milan Kundera was one of the few who succeeded doing this in the novel Nesnesitelná lehkost bytí (The Unbearable Lightness of Being) (1984). The works of such writers as Péter Esterházy, György Spiró, Pavol Rankov, Lajos Grendel, Paweł Huelle, Jerzy Pilch also contain

6 One can imagine that certain poetics, topics, moods, and interpretations interweave, excluding others, which creates a certain type of memorial space.

7 Later, others will say that the attractiveness of borderland narratives is accompanied by falsification, stemming from an incomplete, fragmented and paternalistic approach to issues outside the Polish purview. 
examples of irony that refashion the history of subalterned individuals or nations into an aesthetic object, somewhat putting in parentheses the horrors of the past. Irony can neutralize memory and history in a political or nationalist sense. It opposes ressentiment and historical politics. However, it proves useless in relation to the Holocaust, because no common literary (artistic) language has been invented which, by means of irony, would allow us to come to terms with the deaths of millions, or to understand it as a fact that is completely unexplainable artistically, although it does have its literary representation. Regardless of these shortcomings of irony, the internally conflicted memorial community that has been created in art is certainly accepted. Here, it is possible to say that Hungarians and Poles, together with the Soviets and Eastern Germans, invaded Czechoslovakia in 1968. We would prefer not to talk about this shared history in such a tone, although it would not be easy to unremember this fact and there is no such need. The deep irony of Kundera and Rankov in the novel Stalo sa prvého septembra (alebo inokedy) (It Happened on September First (or Whenever) (2001), the playful grotesque tale about Hungarian-Slovak relations in Grendel's novel Nálunk New Hontban (In Our New Hont) (2001) as well as the grotesque, though unfortunately unsuccessful, ridiculous film Operacja Dunaj (Operation Danube) (dir. Jacek Głomb, 2009) about the Polish participation in the invasion of Czechoslovakia (it is a pity that Poles were not able to produce a more interesting reaction), all support the construction of various areas of shared memory and manage to show other aspects that are not pathetic or tragic. Literature transcends ressentiment, unremembering and historical politics and moves towards empathy and symbolic descriptions that can be treated more universally.

\section{Shared places of Memory: Essence, Value, Consequences}

The purpose of this text was not to draw comparisons between the Central European events of 1956, 1968, and 1981 with other important national experiences in Central and Eastern Europe. What I attempted was to expose that they are characterized by changeability and elusiveness, not by granite durability. The titular events have many things in common: rebellion of the enslaved; invasion from the outside, supported internally by local compradors, traitors and collaborators; mass victims whose memory was almost erased or the significance of their sacrifice diminished with respect to the identities of the defeated and colonized. The rebellion narrative also includes some of the Polish intelligentsia protesting and the authorities brutally pacifying the protest in March 1968. Brutal "internal invasions" are a Polish specialty, if we recall the years 1956, 1970, 1976, and 1981. 
What kind of shared memory and identity will emerge from the processes between postcolonial ressentiment, unremembering, historical politics and aestheticization in such a diverse area as Central and Eastern Europe after 1956? The shared consequences of events include the following: Hungarian, Czechoslovak and Polish societies resigning from further attempts to incite a mass rebellion; consent to "goulash" and "dumpling" communism; a diverse underground resistance, repressions of agents of this resistance; emigration of some citizens, and expulsion of some Poles of Jewish origin from Poland. The memorial, and thus moral, value of these events is presented in various forms and aspects of memory, in the tragedy of many people sacrificing their lives in the name of freedom, and in the impulses of liberty, which gave rise to a mounting resistance against totalitarianism in increasingly more social and national groups.

It is obvious that this memorial community will include heroic rebellions, victims, and a democratic opposition movement against totalitarianism. Collaboration with the system, expulsions and racism, and ambiguous attitudes will be excluded. And yet they constitute an inherent element of the presented events in which Central European subalterns were the participants. The postcolonial perspective reveals what is unwillingly seen in places of shared memory, but what can also be obscured if there was such a will. This is made possible by unremembering and historical politics. At the same time, there is no doubt that we are living in times of frustration and vague ethical messages. That is why shared memory can only emerge in a broader context, one that goes beyond the years 1956, 1968, and 1981.

The question that constantly recurs is what is created and what is omitted by building a shared memory of Central and Eastern Europe; what do we want to exclude from it? An attempt to answer this question would exceed the conceivable scope of this discussion; hence, it seems to me that a vast amount of unarticulated but deeply rooted problems constitute the peculiar contours of "shared" memory of Central and Eastern Europe, which cannot be a full memory of consent and rejection, as it also evokes the unknown areas of non-memory. This is neither surprising nor unique in the postcolonial world. Variously distinguished memory and non-memory can change places (this was the case during the communist era) and then what is shared becomes unambiguous. However, then problems with memory start anew. 


\section{| References}

Bartoś, Tadeusz. "Nienawidzę, więc jestem, czyli skąd się biorą resentymenty”, https://tinyurl.com/y88bxwdo. Accessed 10 August 2018.

Chmel, Rudolf. Slovenská otázka v 20. storočí. Bratislava: Kaligram 1997.

Gyáni, Gábor. A történelem mint emlék(mü). Budapest: Kaligram, 2016.

Gyáni, Gábor. Relatív történelem. Budapest: Typotext, 2007.

Holbwachs, Maurice. Społeczne ramy pamięci. Trans. Marcin Król. Warszawa: PIW, 1969.

Lužný, Dušan. "Kulturní pamět jako koncept sociálních věd." Studia Philosophica 2.61 (2014): 3-18.

Malicki, Krzysztof. Pamięć przeszłości pokolenia transformacji. Warszawa: Scholar, 2012.

Olšáková Doubravka, Kaiserová Kristina, eds. Višegradská pamět či višegradské paměti? Pamět většiny a paměti menšin. Č́tanka textů. Ústí nad Labem: Ústav slovansko-germánských studií FF UJEP, 2014.

Scheler, Max. Resentyment i moralność. Trans. Jan Garewicz. Warszawa: Czytelnik, 1997.

Švaříčková-Slabáková, Radmila. "O paměti, historii, vědomí a nevědomí. Současná bádání v pamětových studiích.” Dějiny - Teorie - Kritika 2 (2007): 323-255.

Szacka, Barbara. Czas przeszły: pamięć - mit. Warszawa: Scholar, 2006.

Tomášek, Marcel and Šubrt, Jiří. “Jak se vyrovnáváme s naší minulostí? České a československé nedávné dějiny prizmatem teorie kolektivní paměti a kvalitativní metodologie (focus groups)." Sociológia 46.1 (2014): 88-114.

Wolff-Powęska, Anna. "Polskie spory o historię i pamięć. Polityka historyczna." Przegląd Zachodni 1 (2007): 3-44.

\section{| Abstrakt}

BogusŁaW BAKUŁA

1956, 1968, 1981 - oblicza środkowoeuropejskiej pamięci.

Uwagi w perspektywie postkolonialnej

Artykuł dotyczy dwóch zagadnień. Pierwsze to problem zbiorowej pamięci przeszłości, w której obrębie autor wyodrębnia pamięć wspólną, pamięć odrębną i nie-pamięć. Pamięć wspólna odgrywa w Europie Środkowej mniejszą rolę niż pamięć odrębna, stanowiąca rdzeń tożsamości narodowej i społecznej. Pamięć 
wspólna jest raczej nieosiągalnym ideałem zgłaszanym przez niektórych polityków i badaczy kultury. Ważną funkcję pełni nie-pamięć, czyli przestrzeń czasowego unicestwiania trudnych spraw związanych z przeszłością. Historia i zbiorowa pamięć są w Europie Środkowej konkurencyjnymi drogami utrwalania przeszłości. Wynika to $\mathrm{z}$ faktu wielowiekowych konfliktów, zmieniających się form ustrojowych, zmiany granic i przede wszystkim odebrania wielu narodom suwerenności. Ta sytuacja spowodowała, że problem dominacji i podległości stał się zasadniczym problemem historii i pamięci zbiorowej.

Druga część artykułu jest poświęcona postkolonialnym aspektom zbiorowej pamięci, w jej ramach zwłaszcza podejściu do wydarzeń i dat 1956, 1968, 1981, związanych z militarną reakcją komunistycznego systemu na próby jego zreformowania. Wydarzenia te, przy wszystkich różnicach, są spowodowane przez przemoc zewnętrzną $(1956,1968)$ lub przemoc wewnętrzną wywołaną naciskiem z zewnątrz (1981). Poprzez stosunek do wybranych elementów przeszłości społeczeństwa Europy Środkowej kształtują też wzajemne relacje. Autor ukazuje problem nieoczywistości wspólnej pamięci wewnętrznej i międzynarodowej przez analizę czterech aspektów: resentymentu, odpamiętywania, polityki historycznej i estetyzacji.

Prezentacja wydarzeń lat 1956, 1968, 1981 w perspektywie wskazanych czterech aspektów postkolonialnej pamięci pokazuje słabe istnienie wspólnych obszarów, nad którymi przeważają pamięć odrębna, deformująca realia historyczne, oraz nie-pamięć. Dowodzi to, że wyjście poza hasła i ogólne deklaracje jest dla społeczeństw Europy Środkowej trudne. Prawdziwa wspólna pamięć to zadanie przyszłości.

Słowa kluczowe: Europa Środkowa; 1956; 1968; 1981; pamięć wspólna; pamięć odrębna; nie-pamięć; teoria postkolonialna; resentyment; odpamiętywanie; polityka historyczna; estetyzacja

\section{| Abstract}

BogusŁaW BAKUŁA

1956, 1968, 1981: The Faces of Central-European Memory: A Postcolonial Perspective

This article deals with two issues. The first concerns the problem of collective memory of the past, which is divided here into shared memory, separate memory and non-memory. Shared memory plays a lesser role in Central Europe than separate memory, the latter being the core of national and social identity. Shared memory 
is an unattainable ideal proposed by some politicians and cultural researchers. A significant role is played by non-memory, which temporarily annihilates difficult matters related to the past. History vies with collective memory in Central Europe as a means of preserving the past. This is the result of centuries-old conflicts, changing political systems, shifting borders and, above all, many nations losing their sovereignty. This situation made the problem of domination and subordination a fundamental problem of history and collective memory.

For this reason, the second part of the article focuses on the postcolonial aspects of collective memory, and in particular on its relation to the events of 1956, 1968, and 1981 connected with the military reaction of the communist system to attempts at reform. These events, with all their historical differences, are caused by external violence $(1956,1968)$ or by internal violence caused by external pressure (1981). Central European societies also shape mutual relations through their attitudes to selected elements of the past. The author of the article depicts the inconspicuous aspects of shared internal and international memory by means of an analysis of four aspects: ressentiment, unremembering, historical politics and aesthetisation.

An analysis of the events that took place in 1956, 1968, and 1981 in the context of these four aspects of postcolonial memory reveals the fragile (moderately strong) existence of common areas. These areas are dominated by non-memory and separate memory, which deform historical realities. This proves that it is difficult for Central European societies to move beyond slogans and general declarations. True shared memory is the task for the future.

Keywords: Central Europe; 1956; 1968; 1981; common memory; separate memory; non-memory; postcolonial theory; resentiment; retrieval memory; historical policy; aesthetisation

\section{| About the Author}

Bogusław Bakuła is Professor in the Institute of Polish Studies at Adam Mickiewicz University in Poznań, Polish and Slavonic philologist. He deals with post-colonial criticism, among other academic interests. Published work: Skrzydło Dedala. Szkice, rozmowy o poezji i kulturze ukraińskiej lat 50.-9o. xx wieku. Poznań: WiS, 1999; Historia i komparatystyka. Szkice o literaturze i kulturze Europy Środkowo-Wschodniej xx wieku. Poznań: Wydawnictwo „Poznańskie Studia Polonistyczne”, 20oo; Eine parallele Welt. Beitrage zur unabhangigen Kultur in Polen 1976-1989. Bielefeld: Societas Pars Mundi Publishing, 2018; Nie zależności. Przypadki literatury i kulury poza cenzurą 1976-1989. Poznań: Wydawnictwo „Poznańskie Studia Polonistyczne”, 2020. 
Edited: Slovnik polských spisovateli̊. Praha: Libri, 200o; Transformacja w kulturze i literaturze polskiej 1989-2004. Poznań: Bonami, 2007; Drogi do wolności w kulturze Europy Środkowej i Wschodniej 1956-20o6. Poznań: KdE, 2007; Comparisons and Texts. Essays on Literature and Culture of Central-Eastern Europe. Poznań: Bonami, 2015; Dyskurs postkolonialny we wspótczesnej literaturze i kulturze Europy Środkowej i Wschodniej. Poznań: Bonami, 2015.

E-mail: bakula.boguslaw@gmail.com 